\title{
Analysis of the Influence of Stakeholder Domination, Engagement, and Organizational Behavior on Project Performance
}

\author{
Muhamad Rizal Abdillah', Mawardi Amin² \\ ${ }^{1}$ Student of the Master Program in Construction Management at Mercu Buana University, Jakarta, Indonesia, \\ ${ }^{2}$ Lecturer of the Master Program in Construction Management at Mercu Buana University, Jakarta, Indonesia, \\ Master of Civil Engineering Program, Mercu Buana University, Jakarta, Indonesia.
}

Corresponding Author: Mawardi Amin

DOI: https://doi.org/10.52403/ijrr.20220212

\begin{abstract}
According to the data from the Central Bureau of Statistics, building construction in the Special Capital Region of Jakarta Province belongs to a construction cluster with the highest realization value compared to civil and other construction. All construction stakeholders in Indonesia have expectations for the achievement of cost and time. In the project implementation, however, there are often quite high obstacles caused by the less-than-optimal management of the project stakeholders themselves, resulting in the disruption of project implementation. This study aims to determine how significant the influence of each stakeholder management factor on project performance is. In addition, this study is also expected to assist in making a good and appropriate stakeholder relationship strategy so that the achievement of project performance can be improved. Ninety-six respondents participated in this study and their responses were analyzed using SEM-PLS. The findings of this study revealed that domination and organizational behavior had a significant influence on project performance. Meanwhile, engagement had no significant influence, but if mediated by organizational behavior, it had a significant influence on project performance. This study can be used as a basis for determining the right organization and human resources to handle building projects in the Special Capital Region of Jakarta Province. For further research, these results can be used as a reference in describing how internal
\end{abstract}

stakeholders interact in an effort to improve project performance.

Keywords: stakeholders, domination, engagement, organizational behavior, project performance

\section{INTRODUCTION}

The Central Bureau of Statistics of the Republic of Indonesia in 2020 released the data on the value of completed construction by province and type of construction. Building construction in the Special Capital Region of Jakarta Province is the type of construction with the highest value of IDR720,451,099 (million) with a portion of forty-eight percent (48\%), followed by civil construction at thirty percent (30\%), and other construction at twenty-two percent (22\%). With such a large portion, the achievement of project cost and time definitely rises the expectation of all stakeholders. There are many projects that fail, one of which is because the project manager cannot manage the stakeholders, whereas project performance is highly dependent on the attention to the stakeholders (Chandra et al, 2011). In the 2018 project on the Design and Build of the School Building Total Rehabilitation in the Special Capital Region of Jakarta Province, there were a total of 98 school buildings which were divided into five projects. Of the 98 schools, only 38 schools or around 
Muhamad Rizal Abdillah et.al. Analysis of the influence of stakeholder domination, engagement, and organizational behavior on project performance.

$39 \%$ were completed on time, while the remaining 60 schools or around $61 \%$

experienced delays.

Table 1 Data on the 2018 Special Capital Region of Jakarta School Building Total Rehabilitation Project Handover

\begin{tabular}{|c|c|c|c|c|c|c|}
\hline \multirow[t]{2}{*}{ No } & \multirow[t]{2}{*}{ Project Title } & \multirow{2}{*}{$\begin{array}{l}\text { Quantity } \\
\text { (Location) }\end{array}$} & \multicolumn{4}{|c|}{ Handover Time } \\
\hline & & & $\begin{array}{ll}06 & \text { Dec } \\
18\end{array}$ & $\begin{array}{ll}20 & \text { Dec } \\
18 & \end{array}$ & $\begin{array}{l}30 \text { Dec } \\
18\end{array}$ & 2019 \\
\hline 1 & $\begin{array}{l}\text { School Building Total Rehabilitation Project } 1 \text { for North Jakarta and } \\
\text { Kepulauan Seribu Area }\end{array}$ & 24 & 3 & 6 & 10 & 5 \\
\hline 2 & School Building Total Rehabilitation Project 2 for West Jakarta Area & 17 & 0 & 5 & 10 & 2 \\
\hline 3 & School Building Total Rehabilitation Project 3 for South Jakarta Area & 15 & 0 & 2 & 8 & 5 \\
\hline 4 & School Building Total Rehabilitation Project 4 for East Jakarta I Area & 19 & 4 & 9 & 6 & 0 \\
\hline 5 & $\begin{array}{l}\text { School Building Total Rehabilitation Project } 5 \text { for Central Jakarta and } \\
\text { East Jakarta II Area }\end{array}$ & 23 & 0 & 9 & 10 & 4 \\
\hline & Total & 98 & 7 & 31 & 44 & 16 \\
\hline
\end{tabular}

Source: PT Virama Karya (Persero) (2019)

In a previous study conducted by Tarigan (2018) on a similar project, namely the Educational Building Total Rehabilitation Project 4 in the Special Capital Region of Jakarta Province in 2017, it was found that there were six risk factors that influenced project delays, namely:

1. Project scope factor (all stakeholders scope)

2. Project owner management capability (project owner scope)

3. Project manager capability (all stakeholders scope)

4. Planning capability (all stakeholders scope)

5. Implementation capability (all stakeholders scope)

6. Procurement process (all stakeholders scope)

Various things can happen in a construction project that may cause an increase in the duration and cost so that the project completion experiences delay. According to Pastiarsa (2015), there are several things that might cause a project to experience delay in its implementation, namely:

1. Project aims and project success criteria are not clear in relation to the uncertainty of the project and the organization's strategic plan

2. Lack of involvement of service users from the beginning of the project and lack of top-level management support and commitment to the project team

3. Lack of effective communication with project stakeholders during the project

The aforementioned factual conditions prove that stakeholder management is an important part of an organization's management strategy in achieving its goals. Managing stakeholders is essential for project managers, in that the stakeholders can greatly influence the construction process in resulting an output. Engaging the stakeholders will realize the development and sustainability of relationships among stakeholders that can maintain or increase the capital and add the social capital (Ayuso et al., 2006). Organizations that can engage their stakeholders actively will gain success (Lerbinger, 2006). Increasing efficiency, strengthening market position, reducing conflict, and identifying business opportunities can be achieved by engaging the stakeholders (Chinyio \& Akintoye, 2008). In general, several project problems are caused by stakeholder management factors. Therefore, it is necessary to conduct an in-depth study of the analysis of domination, engagement, and organizational behavior of stakeholders.

This study aims to determine how significant the influence of each stakeholder management factor on project performance is. By understanding the influence of each stakeholder management factor, project actors can carry out better mitigation and planning to manage the stakeholders.

\section{LITERATURE REVIEW}

Project Performance

Syah (2004) argued that the performance of a project cannot be separated from the factors that influence it either directly or indirectly. The role of the 
project manager is very dominant in the overall project implementation, whereas managerial and technical skills greatly assist the smooth implementation of the project. Yulianto (2005) suggested that one of the critical success factors for a project which also causes the failure of a project is the competence of the project manager. For this reason, the project manager must have the required competency requirements because their competence is one of the important factors to achieve project performance on time. According to Evrianto (2005), delay is an implementation time that is not utilized in accordance with the activity plan, causing one or several activities that follow to be delayed or not completed exactly according to the planned schedule. Delays that occur in a construction project will extend the duration of the project and/or increase costs.

\section{Stakeholder}

Ward and Cahpman (2008) defined stakeholders as groups or individuals who influence and are influenced by the achievement of organizational goals, have influence in providing input, and benefit from the output produced. Cleland (1999) divided stakeholders in the project into two categories, namely internal and external stakeholders. Internal stakeholders include the project management team, subcontractors, employees, project owners, planning consultants, contractors, and suppliers. On the other hand, external stakeholders consist of the government, mass media, business and industry, social services, local residents, local and public communities, mass organizations and political parties, environmental experts, and others. According to Yang J., et al (2009:6), there are factors that influence the success of stakeholders. The five indicators with the highest ranking are: 1) managing social responsibility of stakeholders, 2) exploring the needs and constraints of stakeholders, 3) communicating with and involving stakeholders well and continuously, 4) understanding stakeholder interests, and 5) identifying stakeholders appropriately.

\section{Stakeholder Domination}

According to Mitchell in BonnafousBoucher et al (2012:13), stakeholders can be classified into three criteria, namely stakeholders who have the power to influence (dormant stakeholders), stakeholders who have legitimacy (discretionary stakeholders), and stakeholders who have urgency to the project (demanding stakeholders). The three stakeholder criteria above can be categorized as impact or domination caused by stakeholders. Likewise, Chandra et al. (2011:137) classified the impact of stakeholder domination as follows:

1. Stakeholder urgency, that is, the degree to which stakeholders' demands or claims call for immediate attention.

2. Stakeholder knowledge measured from the degree of concern to total ignorance of project implementation

3. Stakeholder proximity which is defined as the presence of stakeholders related to their relationship with the project

Nguyen (2009) classified the factors that have an impact on the project as follows: (a) Power; (b) Legitimacy; (c) Urgency; (d) Proximity; (e) Vested Interest.

\section{Stakeholder Engagement}

Riedel and Al-Keim (2017) in Rr. Arum Puni Rijanti, Nur Hasanah (2019) defined stakeholder engagement as an important project success factor that has a positive impact on minimizing costs and schedule delays. Stakeholder engagement is very important as it helps in achieving project aims on time, within budget, and with quality (Romenti, 2010; Sallinen et al, 2013). Communication among stakeholders is considered important because it ensures the involvement of all stakeholders through reducing conflict and generating new ideas (Loosemore, 2010; Dawkins, 2004). Greenwood (2007) suggested that there is a relationship between the level of engagement and responsible treatment of stakeholders, and how stakeholder engagement itself is a process of communication, dialogue, and exchange. 
Engaging different stakeholders in the construction sector enables organizations to develop the ability to deliver value to their stakeholders more efficiently and to increase their ability to meet multiple categories of stakeholder satisfaction (Yang et al, 2009). According to Romenti (2010), engaging stakeholders acts as an effort that can encourage and explain the company's identity into concrete organizational behavior. He also added that it enables organizations to be consistent and maintain a temporal alignment between stakeholder expectations and organizational behavior.

\section{Stakeholder Organizational Behavior}

Gibson et al. (2012) defined organizational behavior as multidisciplinary by using principles, models, theories, and methods from other disciplines. The study of organizational behavior is not a generally accepted discipline or science with a wellestablished theoretical foundation, but is a field that has only recently begun to grow and develop in status and impact. Du and El-Gafy (2014:3342) adopted the model from Robbins and Langton (1998) to examine the effect of organizational behavior models in the construction industry based on the agent/actor approach, where in this model, work performance is a human outcome depending on the individual behavior, group behavior, and organizational systems and is influenced by environmental changes and pressures. Meanwhile, Supartha (2017:1) conceptually provided an understanding of organizational behavior as the influence of factors on how people as individuals and as group members behave in organizations and their influence on organizational structures and systems. In general, organizational behavior is a result of the interaction of components within the organization which includes the level of individual behavior, group behavior, and overall organizational behavior. Referring to Colquitt et al. (2011:4), organizational behavior is classified into five groups, namely: (1) organizational mechanisms, (2) group mechanisms, (3) individual characteristics, (4) individual mechanisms, and (5) individual outcomes.

\section{Research Hypotheses}

From the aforementioned description of stakeholders and project performance, the following research hypotheses were formulated:

H1 : There is a significant relationship between stakeholder domination on project performance

$\mathrm{H} 2$ : There is a significant relationship between stakeholder engagement on project performance

H3 : There is a significant relationship between stakeholder organizational behavior on project performance

$\mathrm{H} 4$ : There is a significant relationship between stakeholder domination on project performance through organizational behavior

H5 : There is a significant relationship between stakeholder engagement on project performance through organizational behavior

H6 : There is a significant relationship between the domination, engagement, and organizational behavior of stakeholders on project performance simultaneously

\section{MATERIALS \& METHODS Data Collection}

This study was conducted using a questionnaire submitted to stakeholders in the Special Capital Region of Jakarta Province who have or are currently handling building construction in the 2018-2021 period. The questionnaire contained questions and statements regarding stakeholder management factors.

\section{Material}

This study employed stakeholder management factors based on the literature, consisting of several factors that influence project performance as shown in Table 2 . 
Muhamad Rizal Abdillah et.al. Analysis of the influence of stakeholder domination, engagement, and organizational behavior on project performance.

Table 2 Variables of Domination, Engagement, Organizational Behavior, and Project Performance

\begin{tabular}{|c|c|}
\hline Variable & Description \\
\hline \multicolumn{2}{|l|}{ Domination (DOM) } \\
\hline Power & $\begin{array}{l}\text { How much power or the degree of proximity of stakeholders to the government and how often that power or } \\
\text { proximity is used to influence project implementation }\end{array}$ \\
\hline Legitimacy & $\begin{array}{l}\text { Recognition and acceptance by the work environment regarding the capacity and competency possessed by the } \\
\text { stakeholders including the degree of confidence from the environment regarding the decisions taken can be carried } \\
\text { out on the basis of trust and reputation }\end{array}$ \\
\hline Urgency & $\begin{array}{l}\text { The intensity and ability to put pressure on a certain condition that requires immediate resolution, including attitude } \\
\text { towards unsatisfactory responses }\end{array}$ \\
\hline Proximity & $\begin{array}{l}\text { Intensity of stakeholder involvement in project problem solving, discussion meetings, coordination, and other } \\
\text { technical and non-technical matters affecting project implementation }\end{array}$ \\
\hline Personal Interests & $\begin{array}{l}\text { How much self-interest is shown and demanded for the project and the intensity of the interest demanded in project } \\
\text { implementation. The interests referred to are included in economic, social, cultural motives or legal positions. }\end{array}$ \\
\hline \multicolumn{2}{|l|}{ Engagement (ENG) } \\
\hline Responsibility & Having a great responsibility in the process of implementing the project development \\
\hline Communication & $\begin{array}{l}\text { Having a good communication with all staffs in the project organization, the information given and received can be } \\
\text { clearly understood }\end{array}$ \\
\hline Support & Not against and always supporting good decisions for the sustainability of the project \\
\hline Decision Making & Able to take the right decisions in the implementation of project development \\
\hline \multicolumn{2}{|c|}{ Organizational Behavior (ORG) } \\
\hline $\begin{array}{l}\text { Organizational } \\
\text { Mechanisms }\end{array}$ & $\begin{array}{l}\text { A number of important understandings such as norms, values, attitudes, and beliefs shared by organizational } \\
\text { members and models and forms of organizational structure that can be accepted by other stakeholders or at least can } \\
\text { influence them positively without causing disputes and conflicts }\end{array}$ \\
\hline Group Mechanisms & $\begin{array}{l}\text { How the leadership model, the communication within the team, the characteristics and differences of the team are in } \\
\text { their influence on the pattern of organizational policies and able to resolve any disputes that arise in the project }\end{array}$ \\
\hline $\begin{array}{l}\text { Individual } \\
\text { Characteristics }\end{array}$ & $\begin{array}{l}\text { How much the organization's personnel have competence, managerial ability, analytical ability, and adhere to the } \\
\text { principles of personal goodness in carrying out organizational tasks and influencing organizational policies }\end{array}$ \\
\hline $\begin{array}{l}\text { Individual } \\
\text { Mechanisms }\end{array}$ & $\begin{array}{l}\text { The level of job satisfaction, work pressure, motivation of each individual to carry out organizational tasks as well as } \\
\text { possible based on the organization's belief in fairness, applying professional ethics, as well as learning opportunities } \\
\text { and the right decision-making process }\end{array}$ \\
\hline $\begin{array}{l}\text { Individual } \\
\text { Outcomes }\end{array}$ & $\begin{array}{l}\text { Conformity between performance and organizational commitment to the organization's vision and mission, each } \\
\text { individual can represent the best values of their organization }\end{array}$ \\
\hline \multicolumn{2}{|c|}{ Project Performance (PP) } \\
\hline On Budget & $\begin{array}{l}\text { The project cost does not exceed the cost limit that has been planned or previously agreed upon or in accordance } \\
\text { with the contract for the work implementation }\end{array}$ \\
\hline On Time & $\begin{array}{l}\text { The time to complete the work must meet the time limit agreed in the planning document or the relevant contract } \\
\text { document }\end{array}$ \\
\hline
\end{tabular}

\section{Statistical Analysis}

Questionnaires that were filled out by the respondents were processed with several stages of analysis, namely descriptive statistics and instrument tests consisting of validity and reliability tests. This study using Structural Equation Modeling - Partial Least Square (SEM-
PLS) with WarpPLS 3.0 software as an analytical tool in producing the evaluation of the outer model and inner model. By using this method, the significance of stakeholder management variables that influence project performance was obtained based on the perceptions of the stakeholders involved in the project.

\section{Research Model}

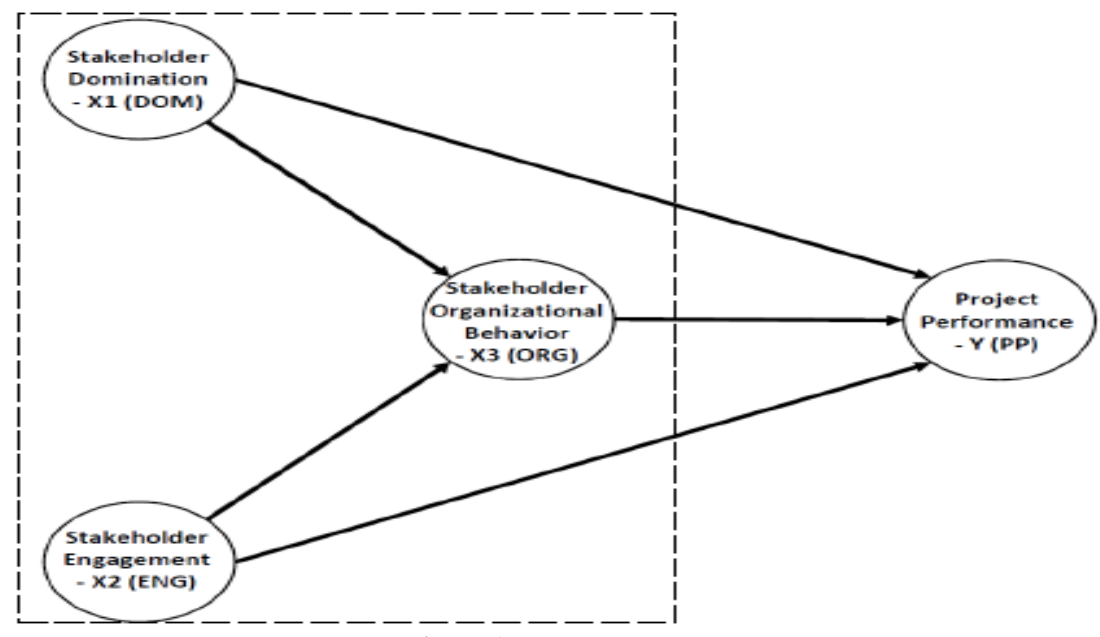

Figure 1 Research Model 
Muhamad Rizal Abdillah et.al. Analysis of the influence of stakeholder domination, engagement, and organizational behavior on project performance.

This study examines the influence of stakeholder interaction based on domination, engagement, and organizational behavior on project performance by using a sample measurement in the Special Capital Region of Jakarta Province.

\section{RESULT}

\section{Data Collection Results}

The qquestionnaires were distributed to 96 stakeholders who have been and are currently managing building projects in the DKI Jakarta Province in the period 2018 2021. Based on the respondent's data in table 3 , it can be concluded that they are sufficient to represent this research which can be seen in the experience or tenure of more than 5 years, and $38.54 \%$ of the respondents have experience or years of service more than 20 years. Moreover, the respondents' minimum educational qualifications are bachelor and master which are $94.79 \%$. The organization in which the respondent works demonstrates diversity and is able to represent the project's internal stakeholders.

Table 3 Respondent Characteristic

\begin{tabular}{|l|l|l|}
\hline Respondent Characteristic & Frequency & Percent \\
\hline Experience as Professional & & \\
\hline 5-10 years & 15 & $15.63 \%$ \\
\hline 10-15 years & 20 & $20.83 \%$ \\
\hline $15-20$ years & 24 & $25.00 \%$ \\
\hline More than 20 years & 37 & $38.54 \%$ \\
\hline Education degree & & \\
\hline Diploma & 3 & $3.13 \%$ \\
\hline Bachelor & 64 & $66.67 \%$ \\
\hline Master & 27 & $28.13 \%$ \\
\hline Doctor & 3 & $2.08 \%$ \\
\hline Tipe of Organization & & \\
\hline Owner & 18 & $18.75 \%$ \\
\hline Construction Management Consultant & 16 & $16.67 \%$ \\
\hline Design Consultant & 17 & $17.71 \%$ \\
\hline Contractor & 28 & $29.17 \%$ \\
\hline Sub-Contractor / Supplier & 17 & $17.71 \%$ \\
\hline
\end{tabular}

The questionnaire used a Likert scale with 5 levels of assessment. The answer of strongly agree is given a score of 5 while strongly disagree is given a score of 1 . With an interval level of 0.8 , the result is that the variable category of this research is in a good range, which is between 3.40 4.20. The average score for each variable sequentially is as follows: Domination of 3.70; Engagement of 3.79; Organizational
Behavior of 3.67; and Project Performance of 3.76 .

\section{Outer Model Evaluation}

This evaluation will be used to measure the loading factor, validity, and reliability. The loading factor is used to see how much the indicator contributes in explaining the construct variable. From the evaluation of this model, there are 3 indicators that have a loading factor value of less than 0.7, namely DOM5, ENG3, and ORG5, so they must be removed from the test model and then re-estimated, because these indicators are considered not to contribute in explaining the measurement construct variables.

Testing the validity of the model also looks at the results of the convergent validity value using the AVE value obtained from the SmartPLS output. The results of the AVE values for each variable of domination, engagement, organizational behavior, and project performance sequentially are as follows: $0.658 ; 0.647$; 0.641 ; and 0.879 . The overall AVE value is above 0.5 so it can be concluded that the convergent validity of all variables is at a good stage.

The estimation results on the model show that all indicators have a higher cross loading value in their respective constructs than the cross-loading value on other constructs so that all indicators have good discriminant validity values. The results show that all constructs have met good discriminant validity because each construct has an AVE root value that is higher than the highest correlation value.

Testing the construct reliability on the model was carried out using the measuring instrument Cronbach's alpha and composite reliability. From the model estimation results, Cronbach's alpha value was above 0.6 and composite reliability was above 0.7 so that all constructs have good reliability. 


\section{The influence of f-square and Q-square predictive relevance}

The f-square value is equal to 0.02 ; 0.15 ; and 0.35 can be interpreted that the latent variable predictor has a small, moderate, and large influence on the structural level. The value of the f-square effect can be seen in table 4 .

The calculations to test the suitability of the model with the research results are determined based on the overall validity and an explanation of the model's capabilities. According to the model estimation results, the Q-square value obtained is 0.769 , which means the value is greater than 0 (zero) so that this measurement model has predictive relevance.

Table 4 Value of f-square Influence

Table 4 Value of f-square Influence
\begin{tabular}{|l|l|l|}
\hline Relation & F square & Conclusion \\
\hline $\mathrm{DOM} \rightarrow \mathrm{PP}$ & 0,074 & Small \\
\hline $\mathrm{DOM} \rightarrow \mathrm{ENG}$ & 0,608 & Big \\
\hline $\mathrm{DOM} \rightarrow$ ORG & 0,037 & Small \\
\hline $\mathrm{ENG} \rightarrow \mathrm{PP}$ & 0,004 & Small \\
\hline $\mathrm{ENG} \rightarrow$ ORG & 0,181 & Medium \\
\hline $\mathrm{ORG} \rightarrow \mathrm{PP}$ & 0,238 & Medium \\
\hline
\end{tabular}

\section{Inner Model Evaluation}

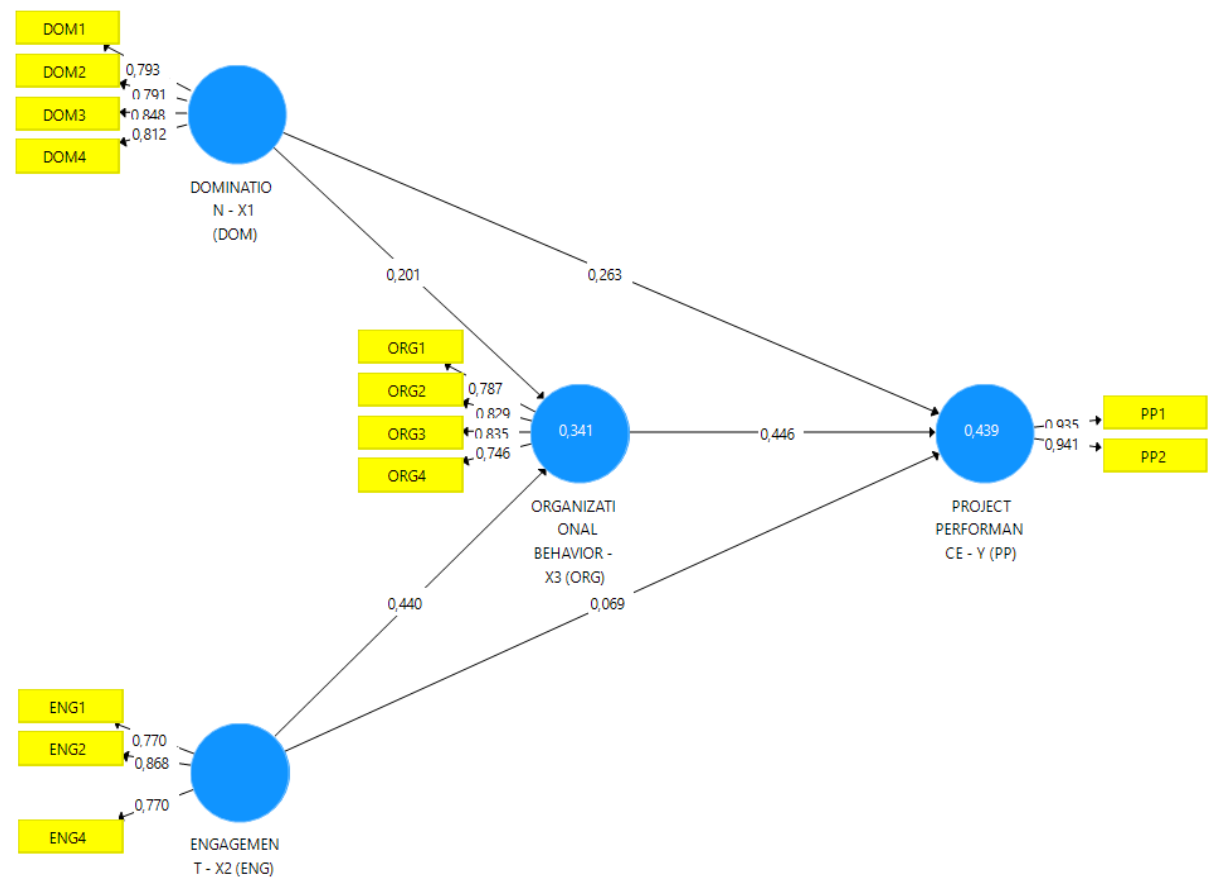

Figure 2 Measurement Model Equation

From the figure of the measurement model above, the equations obtained are as follows:

$$
\begin{aligned}
\mathrm{PP}= & 0.263 \mathrm{DOM}+\mathrm{R}^{2}=0.439 \\
& 0.446 \mathrm{ORG}+ \\
& 0.069 \mathrm{ENG} \\
\mathrm{ORG}= & 0.201 \mathrm{DOM}+\mathrm{R}^{2}=0.341 \\
& 0.440 \mathrm{ENG}
\end{aligned}
$$

Based on these equations, it can be concluded that domination, engagement, and organizational behavior have an influence of $43.9 \%$ on project performance. Stakeholder Organizational Behavior gives the greatest influence according to this equation with a coefficient of 0.446 . Stakeholder domination has a positive contribution of 0.263 and engagement is only able to have an influence on project performance of 0.069 . In the equation of Organizational Behavior, Domination and Engagement have an influence of $34.1 \%$. The greatest influence is given by engagement which contributes an influence of 0.440 in a positive direction. So that organizational behavior is more influenced by engagement than domination which only has a positive influence of 0.201 . 
Muhamad Rizal Abdillah et.al. Analysis of the influence of stakeholder domination, engagement, and organizational behavior on project performance.

\section{Partial Hypothesis Test}

From the model test results, it can be concluded that the hypothesis which states that there is a significant relationship between Domination on Project
Performance (H1) and Organizational Behavior on Project Performance (H3) can be proven. While the significant effect of engagement on project performance $(\mathrm{H} 2)$ cannot be proven in this research.

Table 5 Path Coefficient t-value and Partial Hypothesis

\begin{tabular}{|l|l|l|l|l|}
\hline Relation & Path Coefficient & t-value & Significance & Conclusion \\
\hline $\mathrm{DOM} \rightarrow \mathrm{PP}$ & 0,263 & 2,061 & 0,002 & H1 accepted \\
\hline $\mathrm{ENG} \rightarrow \mathrm{PP}$ & 0,069 & 0,705 & 0,481 & H2 rejected \\
\hline $\mathrm{ORG} \rightarrow \mathrm{PP}$ & 0,446 & 3,915 & 0,000 & H3 accepted \\
\hline
\end{tabular}

\section{Mediation Hypothesis Test}

The estimation of this measurement model is able to prove the significant influence of Organizational Behavior as a mediating variable between Engagement and Project Performance (H5). However, it is not proven that there is a significant effect of Organizational Behavior as a mediating variable between Domination and Project Performance (H4).

Table 6 Mediation Hypothesis
\begin{tabular}{|l|l|l|l|l|}
\hline Relation & Coefficient & t-value & Significance & Conclusion \\
\hline $\mathrm{DOM} \rightarrow \mathrm{ORG} \rightarrow \mathrm{PP}$ & 0,090 & 1,740 & 0,082 & H4 rejected \\
\hline $\mathrm{ENG} \rightarrow \mathrm{ORG} \rightarrow \mathrm{PP}$ & 0,196 & 2,963 & 0,003 & H5 accepted \\
\hline
\end{tabular}

\section{Simultaneous Hypothesis Test}

To determine the effect of the independent variable simultaneously on the dependent variable, the calculation is carried out with the following formula:

$$
F \text { value }=\frac{(n-k-1) R^{2}}{k\left(1-R^{2}\right)} \quad \text { are obtained as in table } 7 .
$$

Table 7 Simultaneous Hypothesis Testing Model
\begin{tabular}{|l|l|l|l|}
\hline Relation & F value & F Table & Conclusion \\
\hline DOM, ENG, and ORG $\rightarrow \mathrm{PP}$ & 23,998 & 2,70 & H6 accepted \\
\hline
\end{tabular}

F table is obtained from the table using the instruments DF1 and DF2, with a total sample of 96 and 3 variables, so the $F$ table is 2.70 . By using the formula, $\mathrm{f}$ value and $\mathrm{f}$ table can be calculated and the results
Based on the table above, it can be proven that the three variables of domination, engagement, and organizational behavior have a significant influence on project performance.

\section{DISCUSSION}

Based on the results of hypothesis testing on the research model, it can be seen that in the $\mathrm{H} 1$ hypothesis there is a significant relationship between domination and project performance can be proven. This hypothesis finds the same results as research conducted by Sanggoro (2020) and Chandra (2011) which concluded that there was a significant influence of stakeholder domination on project performance. In general, with this measurement model, the influence of Domination is still quite strong in its role in building projects. Meanwhile,
Stakeholder Organizational Behavior is not able to exert a mediating effect between Stakeholder Domination and Project Performance (H4 is rejected).

Meanwhile, hypothesis $\mathrm{H} 2$ in this sample research did not find a significant direct relationship between stakeholder engagement on project performance. The results of this hypothesis contradict the results of research by Wachi (2016) and Bal (2013) which found a significant direct effect of stakeholder engagement on project performance. From the mediation test, the role of Stakeholder Organizational Behavior has a significant effect on the indirect relationship between Stakeholder Engagement and project performance (H5 is proven). This indicates that the Engagement it has in its indirect relationship contributes 
to project Performance if it is mediated by good Organizational Behavior.

Hypothesis H3 which states there is a significant influence between Stakeholder Organizational Behavior on project performance. This hypothesis finds the same results as research conducted by Darmanto (2019) which concluded that there was a significant effect of Stakeholder Organizational Behavior on Construction Performance. While the influence on Organizational Behavior, $34.1 \%$ can be explained well by Domination and Engagement. The value of the path coefficients for Domination on Organizational Behavior is 0.201 and between Engagement on Organizational Behavior is 0.440. Thus, Stakeholder Engagement can better explain the quality of Stakeholder Organizational Behavior than Stakeholder Domination.

Simultaneous, Domination, Engagement, and Organizational Behavior have a significant influence on project performance. This conclusion shows that Hypothesis $\mathrm{H} 6$ can be proven in the estimation of this measurement model. From the explanation of the proof of the hypothesis, in detail, it shows that from $43.9 \%$ the influence of project performance can be explained well by Domination, Engagement, and Organizational Behavior. The path coefficient values are 0.263 between Domination on Project Performance, 0.069 between Engagement on Project Performance, and 0.446 between Organizational Behavior on Project Performance. The equation shows that the role of Stakeholder Organizational Behavior has a greater influence than the other two variables.

The indicators that contribute to explaining the variables in this study are as shown in table 8 .

Table 8 Loading Factor Value of Indicator Contribution

\begin{tabular}{|l|l|l|}
\hline Variable & Indicator & Loading Factor \\
\hline \multirow{4}{*}{ Stakeholder Domination (X1) } & Power (DOM1) & 0,793 \\
\cline { 2 - 3 } & Legitimation (DOM2) & 0,791 \\
\cline { 2 - 3 } & Urgency (DOM3) & 0,848 \\
\cline { 2 - 3 } & Proximity (DOM4) & 0,812 \\
\hline \multirow{4}{*}{ Stakeholder Engagement (X2) } & Responsibility (ENG1) & 0,770 \\
\cline { 2 - 3 } & Communication (ENG2) & 0,868 \\
\cline { 2 - 3 } & Decision Making (ENG4) & 0,770 \\
\hline \multirow{5}{*}{ Stakeholder Organizational Behavior (X3) } & Organizational Mechanism (ORG1) & 0,787 \\
\cline { 2 - 3 } & Group Mechanism (ORG2) & 0,829 \\
\cline { 2 - 3 } & Individual Characteristic (ORG3) & 0,835 \\
\cline { 2 - 3 } & Individual Mechanism (ORG4) & 0,746 \\
\hline \multirow{2}{*}{ Project Performance (Y) } & Cost Performance (Y1) & 0,935 \\
\cline { 2 - 3 } & Time Performance (Y2) & 0,941 \\
\hline
\end{tabular}

From the table 8 , it can be explained that in the project performance variable, the Time Performance indicator (Y2) has a loading value of 0.941 and is higher than the Cost Performance indicator (Y1) which has a loading value of 0.935 . Meanwhile, in the Stakeholder Domination variable, respondents stated that the Urgency indicator (DOM3) can be explained in this interaction model very well. The loading value of the Urgency (DOM3) indicator is 0.848 and better than the Proximity (DOM4), Power (DOM1), and Legitimacy (DOM2) indicators. In the Stakeholder Engagement variable (X2), respondents stated that the Communication indicator (ENG2) can be explained very well which has a loading value of 0.868 and better than the Decision Making (ENG1) and Responsibility (ENG4) indicators. In the Stakeholder Organizational Behavior variable (X3) respondents stated that the Individual Characteristics (ORG3) indicator could be explained very well. The Individual Characteristics indicator (ORG3) has a loading value of 0.835 and then the indicators of Group Mechanism (ORG2), Organizational Mechanism (ORG1), and Individual Mechanism (ORG4) 


\section{CONCLUSION}

The results of this study provide an overview of stakeholder interactions in the DKI Jakarta Province as measured by the variables of Domination, Engagement, and Organizational Behavior on Building Project Performance. From all samples processed in this study, it can be concluded as follows:

1. Stakeholder domination consistently has a significant influence on project performance. The greater the domination owned by the stakeholders, the greater the ability to directly contribute to project performance. Domination contributed 0.263 , thus it became one of the parameters that need to be consider in the interaction of stakeholders in building projects in the DKI Jakarta Province.

2. Stakeholder engagement has no direct influence on success. However, with the mediation of organizational behavior variables, engagement can be accepted as a variable that has a significant influence on interaction patterns that determine project performance. The influence of engagement on project performance through increasing organizational behavior is able to provide a significant positive contribution to project performance of 0.440. As a result, the stakeholder engagement does not directly have a positive impact that can improve project performance, unless the they are supported by good organizational behavior.

3. Stakeholder organizational behavior is a variable that consistently influences project performance, either directly as a criterion variable or as a moderating variable. This proves that organizational behavior is an important parameter for project performance.

4. Simultaneously, the variables of domination, engagement, and organizational behavior of stakeholders have a positive impact and significantly affect project performance. In this study, information was obtained that the influence that could be explained on project performance by the three variables was $43.9 \%$, in other words that the variables of domination, engagement, and organizational behavior had a moderate influence (Rsquare $>30 \%$ ) on the overall project performance.

\section{Acknowledgement: None}

Conflict of Interest: None

\section{Source of Funding: None}

\section{REFERENCES}

1. Akintoye, Chinyio, E., \& Akintola. (2008). Practical Approaches for Engaging Stakeholders: Finding from the UK. Construction Management and Economics, 591-599.

2. Al-Keim, A., \& Riedel, E. (2017). Strategies to Reduce Cost Overruns and Schedule Delays in Construction Projects. United States: Walden Universuty.

3. Ayuso, S., Rodriguez, M. A., Castro, R. G., \& Arino, M. A. (2011). Does Stakeholder Engagement Promote Sustainable Innovation Orientation? Industrial Management \& Data Systems, 1399-1417.

4. Badan Pusat Statistik. (2020, December). Konstruksi dalam Angka 2020. pp. 21-22.

5. Bal, M. (2014). Stakeholder Engagement and Sustainability-Related Project Performance in Construction. Liverpool: Liverpool John Moores University.

6. Boucher, B., Maria, \& Rendtorff, J. D. (2012). Stakeholder Theory: A Model for Strategic Management. Ethics: SpringerBriefs.

7. Chandra, H. P., Indarto, Wiguna, I. A., \& Kaming, P. F. (2011). Peran Kondisi Pemangku Kepentingan dalam Keberhasilan Proyek. Jurnal Manajemen dan Kewirausahaan, 135-150. 
8. Chapman, Ward, S., \& Chris. (2008). Stakeholders and Uncertainlty Management in Projects. Construction Management and Economics, 563-577.

9. Colquitt, J. A., LePine, J. A., \& Wesson, M. J. (2011). Organizational Behavior: Improving Performance and Commitment in the workplace. New York: McGraw-Hill Irwin.

10. Darmanto, Soehari, T. D., \& Husin, A. E. (2019). Strengthening Project Performance with Organizational Culuture and Project Management Office (PMO) on the Construction of High-rise Building. International Journal of Civil Engineering and Technology, 1809-1818.

11. Dawkins, J. (2004). Corporate responsibility: the communcation challenge. Journal of Communication Management, 108-119.

12. Du, J., \& El-Gafy, M. (2014). Modeling Organizational Behaviors of Construction Enterprises: an Agent Based Modeling Approach. Institute of Electrical and Electronics Engineers, 3341-3362.

13. Ervianto, W. I. (2005). Manajemen Proyek Konstruksi (edisi revisi). Yogyakarta: Andi Offset.

14. Gibson, J. L., Ivancevich, J. M., \& Donnelly, J. H. (2012). Organizations: Behavior, Structure, Processes, Fourteenth Edition. New York: McGraw-Hill Irwin.

15. Greenwood, M. (2007). Stakeholder Engagement: Beyond the Myth of Corporate Responsibility. Journal of Business Ethics, 315-327.

16. Lerbinger, O. (2005). Corporate Public Afairs: Interacting with InterestGroups, Media, and Government (1st edition). New York: Routledge.

17. Loosemore, M. (2010). The Influence of Communcation structure upon management efficiency. Construction Management and Economics, 661-671.

18. Nguyen, Hong, N., Skitmore, Martin, Wong, \& Wai, J. K. (2009). Stakeholder Impact Analysis of Infrastrcuture Project
Management in Developing Countries. Construction Management and Economics, 1129-1140.

19. Olander, S. (2003). External Stakeholder Management in the Construction Process. Sweden: Construction Management Lund University.

20. Pastiarsa, M. (2015). Manajemen Proyek Konstruksi Bangunan Industri: Perspektif Pemilik Proyek. Yogyakarta: Teknosain.

21. PT Virama Karya (Persero). (2019). Data Serah Terima Proyek Rehabilitasi Total Gedung Sekolah DKI Jakarta 2018. Jakarta: PT Virama Karya (Persero).

22. Rijanti, R. P., \& Hasanah, N. (2019). Peran Pemangku Kepentingan dalam Mendukung Pembangunan PLTN. Prosiding Seminar Nasional Infrastruktur Energi Nuklir 2019 (pp. 453-460). Pontianak: PKSEN.

23. Romenti, S. (2010). Reputation and Stakeholder Engagement: an Italian case Study. Journal of Communication Management, 306-318.

24. Sallinen, L., Ruuska, I., \& Ahola, T. (2013). How Governmental Stakeholders Influence Large Projects: The Case of Nuclear Power Plant Projects. International Journal of Managing Projects in Business, 51-68.

25. Sanggoro, H. B., Widyaningsih, N., \& Bintoro, B. P. (2020). Analysis Influence Factors of Domination, Competency and Interpersonal Skill in the Stakeholder Interaction to Infrastructure Project Success. International Journal of Engineering \& Technology, 164-174.

26. Supartha, I. G. (2017). Pengantar Perilaku Organisasi. Denpasar Timur: CV. Setia Bakti.

27. Syah, M. S. (2004). Manajemen Proyek Kiat Sukses Mengelola Proyek. Jakarta: Gramedia Pustaka Utama.

28. Tarigan, A. M., Abdullah, A., \& Rani, H. A. (2018). Faktor-Faktor Risiko Design and Build yang Mempengaruhi Kesuksesan Proyek Rehabilitasi Total 
Muhamad Rizal Abdillah et.al. Analysis of the influence of stakeholder domination, engagement, and organizational behavior on project performance.

Gedung Pendidikan di Provinsi Daerah Khusus Ibukota Jakarta. Journal of Archive in Civil Engineering and Planning, 156-165.

29. Wachi, B. (2016). Assessing the Scope and Effectiveness of Stakeholder Engagement in the Development and Implementation of the Environmental Management Plan for the Berg Water Project in the Western Cape Province, South Africa. Cape Town: University of Cape Town.

30. Yang, J., Shen, Q., \& Ho, M. (2009). Exploring Critical Success Factors for Stakeholder Management in
Construction Project. Journal of Facilities Management, 159-175.

31. Yulianto, O. (2005). Pengaruh Kompetensi Manajer Proyek Kontraktor terhadap Kinerja Waktu Penyelesaian Proyek Konstruksi Studi Kasus PT. X. Jurnal Teknik Sipil, 317-328.

How to cite this article: Muhamad Rizal Abdillah, Mawardi Amin. Analysis of the influence of stakeholder domination, engagement, and organizational behavior on project performance. International Journal of Research and Review. 2022; 9(2): 82-93. DOI: https://doi.org/10.52403/ijrr.20220212 